\title{
Human-Elephant Conflict in Sonamukhi C.D. Block of Bankura District, West Bengal
} Utpal Panja $^{+*}$ and Biswaranjan Mistri ${ }^{\top}$

\begin{abstract}
Human-Elephant Conflict (HEC) is a complex interaction between humans and elephants. This article is an attempt to examine the HEC in the Sonamukhi block of Bankura District. This block is an HEC-affected area, where the increasing human population density and the changing land-use patterns continuously reduce the naturally dwelling place of the elephants. As a result of the reduced geographical spaces, the elephant herds destroy crops, houses, and even kill people. Irritated farmers in return hit back by shooting, wounding elephants with home-made weapons. The conflict burgeons every day. This research article is an outcome of the empirical investigation to chalk out the major causes and consequences of this conflict due to changing behaviour of the wild elephants and the land use patterns of the affected people.
\end{abstract}

Keywords: Human-Elephant Conflict (HEC), Land use patterns, Bankura District, West Bengal

\footnotetext{
${ }^{\dagger}$ Guest Lecturer, Purnidevi Chowdhury Girls' College, Bolpur, Email: utpalpanja87@gmail.com ${ }^{*}$ Corresponding Author

İAssistant Professor, Department of Geography, The University of Burdwan, Email: brmistri@gmail.com (C) 2018 Panja and Mistri. This is an Open Access article distributed under the terms of the Creative Commons Attribution License (http://creativecommons.org/licenses/by/2.0), which permits unrestricted use, distribution, and reproduction in any medium, provided the original work is properly cited.
} 


\section{Introduction}

Human-Wildlife Conflict (HWC) involves any form of interactions between man and wildlife that could bear a harmful effect on either human or wildlife population (Madden, 2004).The elephant is one of the most conflictprone wildlife species in India, causing largescale damage to crops and human lives (Gubbi, 2012). Globally, as well as in India, habitat loss and the expanding of the human population (Chartier, 2011) drive the human-elephant conflict (HEC). HEC is not a new phenomenon; It records the existence of elephant crop raiding in Asia as early as 300 B.C. Now in recent decades the conflict frequency and intensity are increasing day by day in Asia and Africa (Chartier, 2011; Sukumar, 1994; Hoare, 1995). The conflict occurs when elephants feed on crops, destroy farms or homes, injure, or kill people and people retaliate against these losses (Sukumar, 1994; Inskip and Zimmermann, 2009). Studies have shown that large-scale forest encroachment due to large-scale agricultural expansion in Assam, India, has led to increasing levels of HEC (Wilson et al., 2013). Elephants, in search of food and water, tend to enter into human habitations and in the process, often come into direct conflicts (Sukumar, 1994). Crop raiding by elephants can severely affect local livelihoods and additionally, causes increased labour costs, heightened levels of stress and create fear (Lee and Graham 2006; Walker, 2012). The loss of corridors and migratory routes of long-ranging animals like elephants are the major reasons for increasing HEC conflict in Orissa (Palita, 2011). The southern part of West Bengal mainly Bankura, Purulia, and East Midnapore districts are very much affected by HEC. Here, the migratory and the local elephants wander throughout the year (Anon, 2010). (Singh et al., 2002) has shown the elephant depredation about the land use and land cover map of southern West Bengal, mainly in the three districts, and at the same time, he indicates the entry and the return route of the elephant herd. The impact of HEC may be categorised into two types. The Direct HEC impacts upon the physical and economic well beings of rural communities by causing damage of crops, property, livestock and human injury or death, whereas the indirect HEC causes social impacts upon people (Parker et al., 2007).

HEC simply means the friction between Humans (Homo Sapiens Sapiens) and Elephant (Elephas Maximus) for sharing space and food (Kulandaivel, 2010). This conflict is now emerging as a crucial problem in large parts of India including North East India and the Rarh Bengal of West Bengal. In this research, we investigate the HEC in Sonamukhi C.D. Block of Bankura District, which located in the Rarh Bengal region. Here, most of the villagers depend on agricultural activities. Farmers invest their physical toil and money in agricultural land. An Elephant herd of 70-90, moves through the cropping field, eats the crops, destroys the cropping field, and has affected 49.33\% (2015-16) agricultural land. This HEC is increasing on a daily basis, and the inhabitants of the Sonamukhi Block are enormously suffering from crop damage, market garden damage, destruction of houses, in some cases killing or injuries of the people and the seasonal out-migration.

At the heart of this research is to show the causes and consequences of elephants' migration from Dalma range of Jharkhand to the Bankura district of West Bengal in general and Sonamukhi block in particular. At the same time, it tries to analyse how gradually this migration is transformed into a conflict when the elephant herd struggle to share space and food with the humans concerning time. As people apply various unscientific methods to minimise the destruction, the destructive patterns of the herd lead to killing or injury of the humans. These conflicts are kindled both by migratory as well as local elephants and are greatly influenced in particular seasons (Table 1). The most interesting event is that there is a strong relation between crop maturity and the crop-raiding incidents by the herd. The Google image and the Gram Panchayat (G.P.)-wise conflict zone map helps to identify the frequency/intensity of crop raiding and destruction patterns of the elephant herd. In 
the final sections of this research, some ways are recognised for reducing the conflict events as well as create a sustainable environment for the elephants. The next section describes the study area.

\begin{tabular}{|c|c|c|}
\hline Seasons & Damage Types & Attacked by \\
\hline 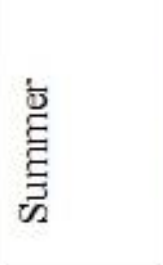 & $\begin{array}{l}\text { Agricultural Crop (Paddy in Harvesting Season) } \\
\text { Commercial Cash Crop (Jack fruit, Sugar cane, } \\
\text { Banana) } \\
\text { Others (Farm House, Household Storage grain, Hut, } \\
\text { Pond and Tank) }\end{array}$ & $\begin{array}{l}\text { Local Elephant } \\
\qquad(10 \text { no.) }\end{array}$ \\
\hline 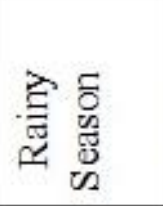 & $\begin{array}{l}\text { Agricultural Crop (Paddy) } \\
\text { Fru it Crop (Banana) } \\
\text { Others (Farm House, Household Storage grain) }\end{array}$ & $\begin{array}{l}\text { Local Elephant } \\
\qquad(7-10 \text { no.) }\end{array}$ \\
\hline 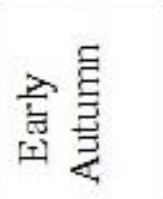 & $\begin{array}{l}\text { Agricultural Crop ( Milky stage of Paddy growth) } \\
\text { Fru it Crop (Banana) } \\
\text { Others (Farm House, Household Storage grain, Hut) }\end{array}$ & $\begin{array}{l}\text { Both Local and } \\
\text { Migratory Elephant } \\
\quad(90-100 \text { no.) }\end{array}$ \\
\hline$\stackrel{\stackrel{\rightleftarrows}{\rightleftarrows}}{\stackrel{\Xi}{\Xi}}$ & $\begin{array}{l}\text { Agricultural Crop ( Mature stage of Paddy growth) } \\
\text { Fru it Crop (Banana, Sugar cane) } \\
\text { Others (Farm House, Household Storage grain) }\end{array}$ & $\begin{array}{l}\text { Local Elephant } \\
\text { (10 no.) }\end{array}$ \\
\hline 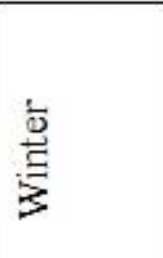 & $\begin{array}{l}\text { Horticu ltural Crop (Vegetable like Potato, Brinjal, } \\
\text { Cabbage, Cauliflower) } \\
\text { Agricultural Crop (Paddy, Wheat, Oil seed) } \\
\text { Fru it Crop (Banana, Sugar cane) } \\
\text { Fru it Crop (Banana, Sugar cane) }\end{array}$ & $\begin{array}{l}\text { Both Local and } \\
\text { Migratory Elephant } \\
\quad(90-100 \text { no.) }\end{array}$ \\
\hline 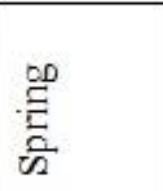 & $\begin{array}{l}\text { Fru it Crop (Banana, Sugar cane) } \\
\text { Others (Farm House, Household Storage grain, Hut, } \\
\text { Pond and Tank) }\end{array}$ & $\begin{array}{l}\text { Local Elephant } \\
\text { (7- } 10 \text { no.) }\end{array}$ \\
\hline
\end{tabular}

Table 1: Seasonal conflict between Humans and Elephants (2016)

\section{Study Area}

Sonamukhi Block is a Community Development (C.D.) unit in Bishnupur subdivision of Bankura District, West Bengal. This district is located in the western part of West Bengal known as Rarh region (Figure 1). Geologically, this region belongs to Archaen-Dharwarian rock system and is an extended part of the peninsular mass of Chhotanagpur plateau. A variety of rocks like gneiss, granite, quartz, sandstone and alluvial with lateritic soil are found. Geomorphologically, undulating with medium slope (District Disaster Management Plan, 2016, Bankura), lithologically, it is alluvial tract with red soil (Malley, 1908), climatologically comes under tropical dry sub-humid climate and culturally the region has a special trait character which gives a unique identity and introduced as a special district in Rarh Bengal of West Bengal. Sonamukhi is, therefore, such a block which is unique regarding geology, geomorphology, lithology, climatology, culturally as well as biologically. It is bounded by $23^{\circ} 10^{\prime} \mathrm{N}$ to $23^{\circ} 25^{\prime} \mathrm{N}$ and $87^{\circ} 15^{\prime} \mathrm{E}$ to $87^{\circ} 30^{\prime}$ $E$. Out of ten Gram Panchayats (G.P) of this 
block, five G.Ps such as Dhansimla, Manikbazar, Kochdihi, Panchal and Hamirhati suffer terribly from HEC. This conflict is considered as a battle, and the agricultural land is the battlefield where the friction occurs. On the one hand, the humans' wants to save the crops for their survival; on the other hand, elephants use the cropping lands to fulfil their huge calorific demand to survive. It is not a war of power, not a war to show bravery, not a war of killing or death but a war for stay alive from the clutches of starvation on both sides. The objectives and the methods of the study are shown below.

\section{Objectives of the Study}

The basic objectives of the empirical investigation are mentioned below:

- To study the major causes of HEC in the study area

- Find out the changes in land use patterns and the changing movement patterns and food habits of the wild elephants.

\section{Database and Method}

This research work was developed with the help of both primary and secondary data. The collection of primary data was based on the indepth interviews at the grassroots level, doorto-door survey method with 225 households of the block. This, in turn, helped us to understand the causes of elephants' migration from the Dalma range. These elephants have lived in the study area for a long time. Using the narrating method, we enquired about the feelings of the residents about human-elephant relations. The respondents narrated some events of HEC occurring in the study area. Secondary data have been collected from the census reports, books, journals, and statistical handbooks. Field observations and perception study have been applied to make the sequential structure of theoretical framework with the help of model, charts and we established the relationships through scattering, correlation coefficient ( $r$ ) and student ${ }^{\prime} \mathrm{t}$ ' test. Observations, recording, and interpretation were the principal processes deployed for this research (see Figure 2). 

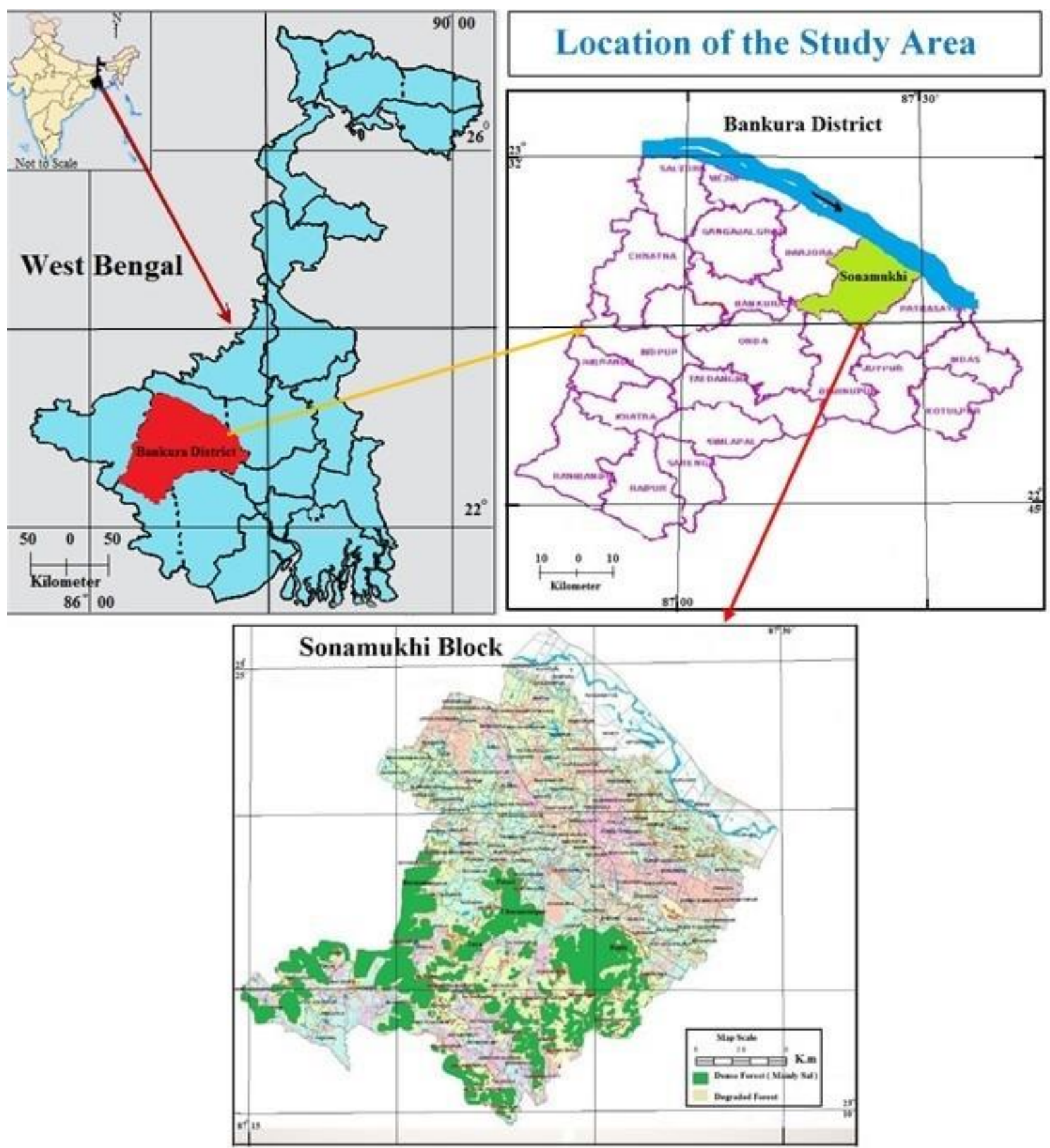

Figure 1: Location of the study area

Source: Prepared by the authors with the help of GPS points, during field survey, 2016

\begin{tabular}{|c|c|c|c|c|}
\hline $\begin{array}{l}\text { Observation } \\
\text { Phenomena/Events } \\
\text { Activities (Natural/Human) } \\
\text { Perception of People }\end{array}$ & $\Rightarrow$ & $\begin{array}{l}\quad \text { Recording } \\
\text {. Information collection } \\
\text { Pot to plot Land use survey } \\
\text { List of Collected data }\end{array}$ & $\Rightarrow$ & $\begin{array}{c}\text { Interpretation } \\
\text {. Analysis of recorded data }\end{array}$ \\
\hline
\end{tabular}

Figure 2: Major processes of field study 


\section{Results and Discussion}

\section{Push and Pull Factors of Elephants' Migration}

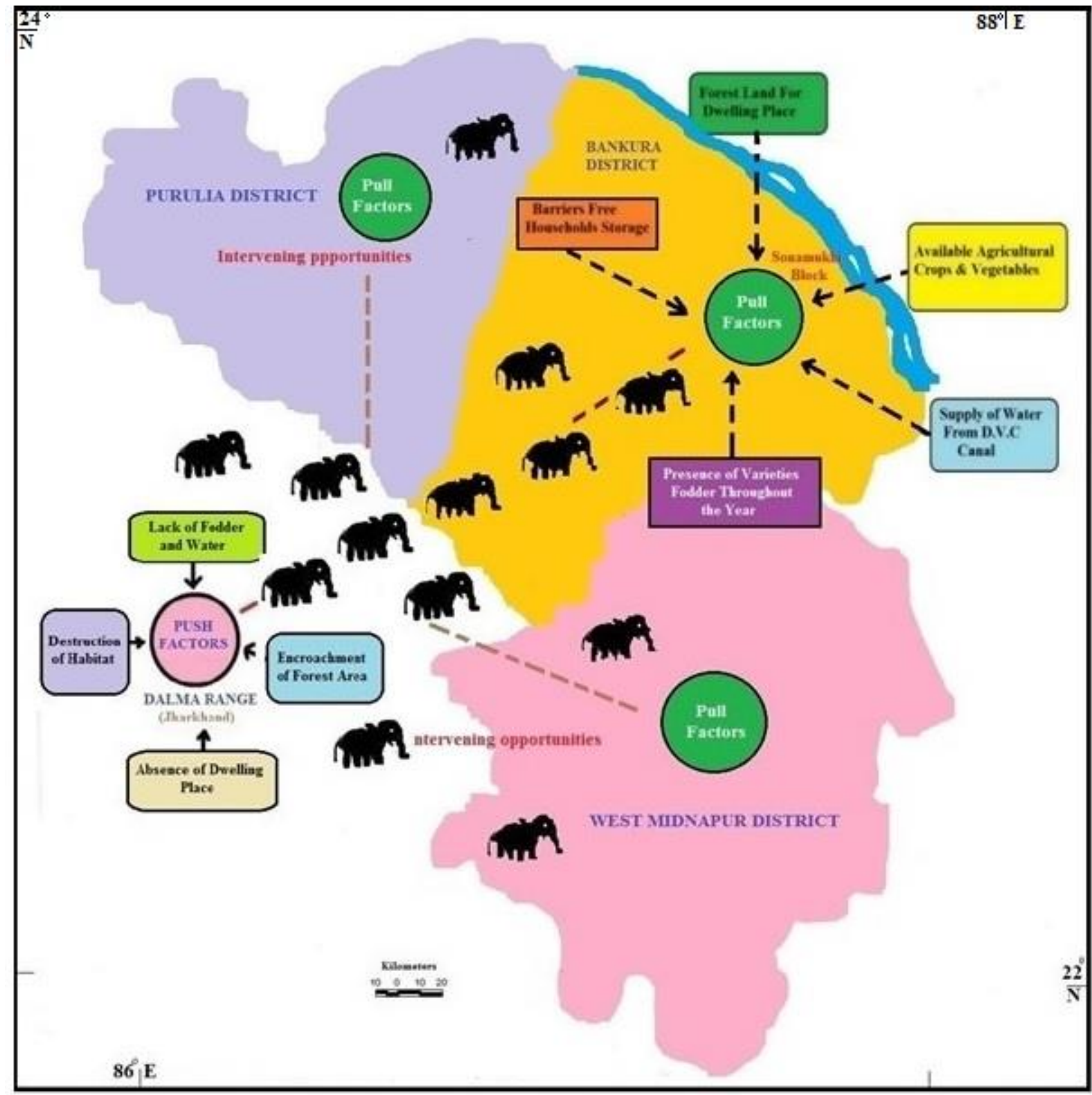

Figure 3: Push and pull factors causing migration of Elephants (2000-2016)

Source: Prepared by the authors based on perception study of the respondents, 2016

The elephants emerge from the Dalma range of Jharkhand and gradually migrate into Bankura, West Midnapur and the Purulia districts of West Bengal. The influencing push factors causing migration of elephants are - lack of food, water, and destruction of habitats, encroachment of forest and the reduction of the dwelling place of the elephants. Not only the push factors but also the pull factors, (Chanda, 1996) which are shown in Figure 3 (and below) are considered as key causes for migration of the elephants to the study area.
- Availability of crops like paddy, wheat, etc. in the cropping fields, which are located adjacent to the forest of the study area.

- Presence of a variety of seasonal vegetables such as potatoes, tomatoes, cabbage, cauliflower, pumpkins, and gourds are available in most patches of the forest area or in the vegetable gardens of the locals throughout the year. 
- Variety of fruit crops such as jackfruits, banana, watermelon and sugarcane are available in the farmers' gardens.

- Adequate water, which is available in the D.V.C (Damodar Valley Corporation) canal helps in drinking and bathing of the elephant herds.

- Deep Sal (Shorea Robusta) forest are used as dwelling place through which the herds can travel freely.

\section{Migration Route of the Elephant Herd}

Chanda (1996), (Figure 4), identifies the migration route of the elephant herds in southern West Bengal and the travel pathways of the herds in Sonamukhi Block are recorded during our field survey and are displayed in Figures 5 and 6.

S.Chanda (in Man- Elephant confict in south West Bengal') shows the movement of uld tlephant in the south west benzal. He divided the movement route into two forms they are as follows:

Movement Route:

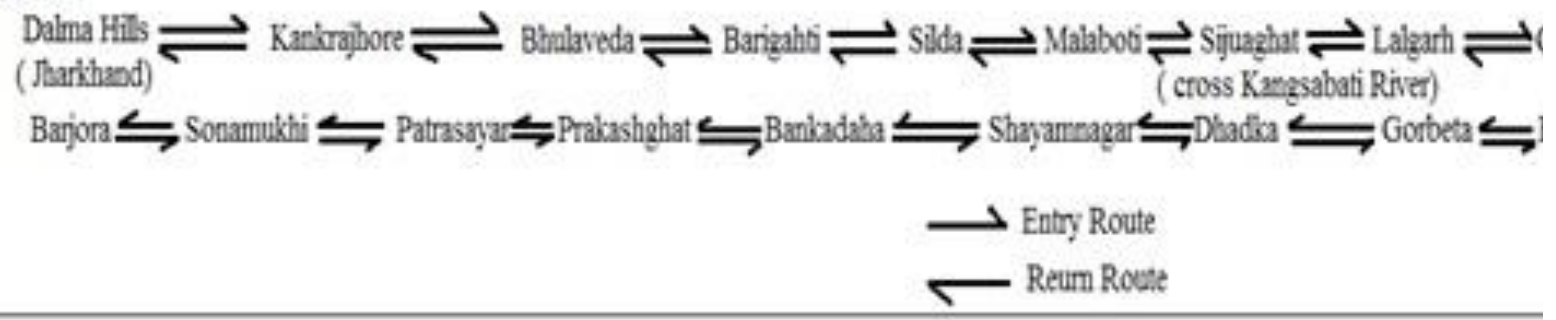

Figure 4: Migration route of Elephants in South-west Bengal

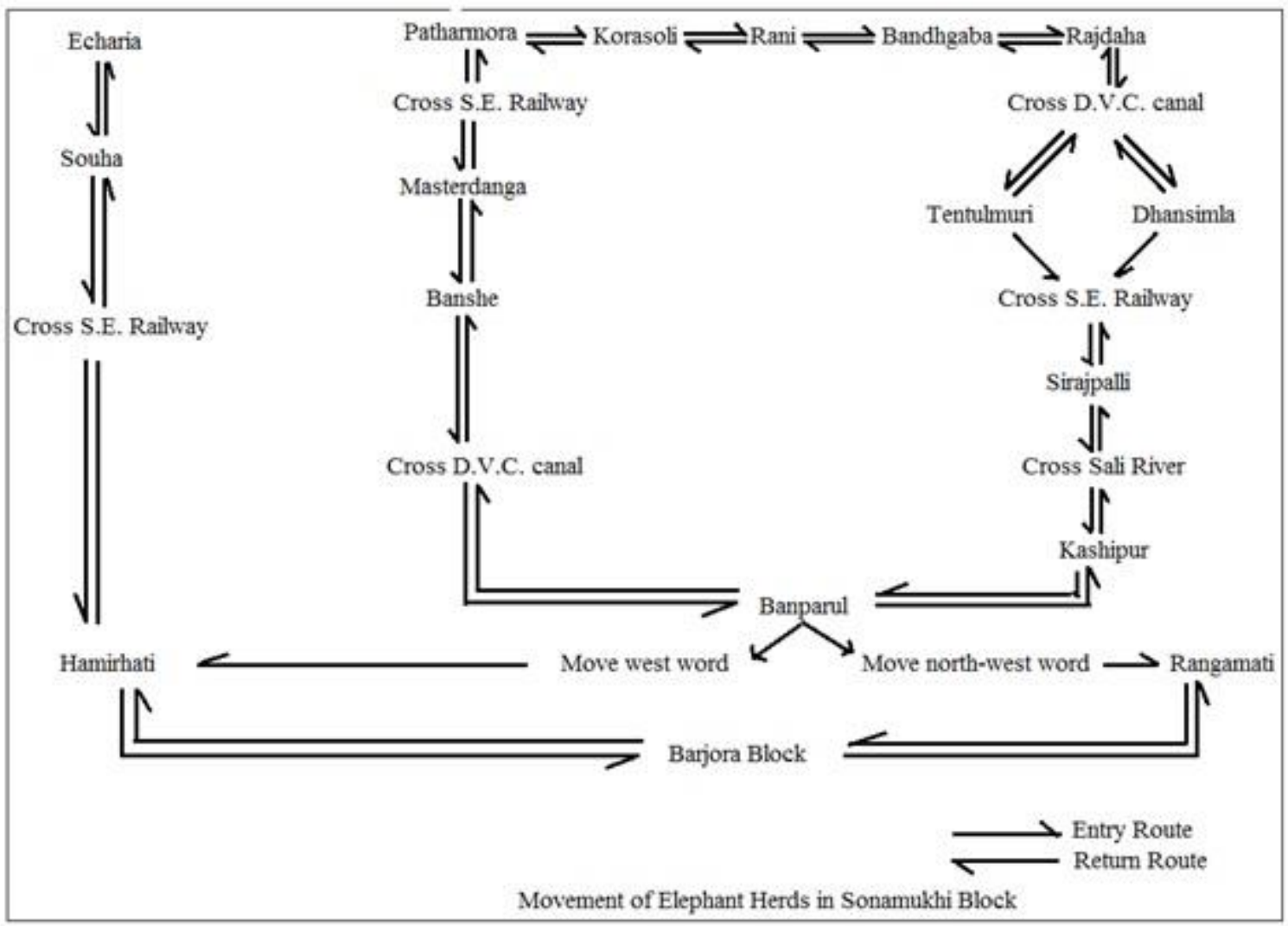

Figure 5: Travel pathway of Elephants in the study area (2000-2016)

Source: Travel track recorded by the authors with GPS and perception study of the villagers, 


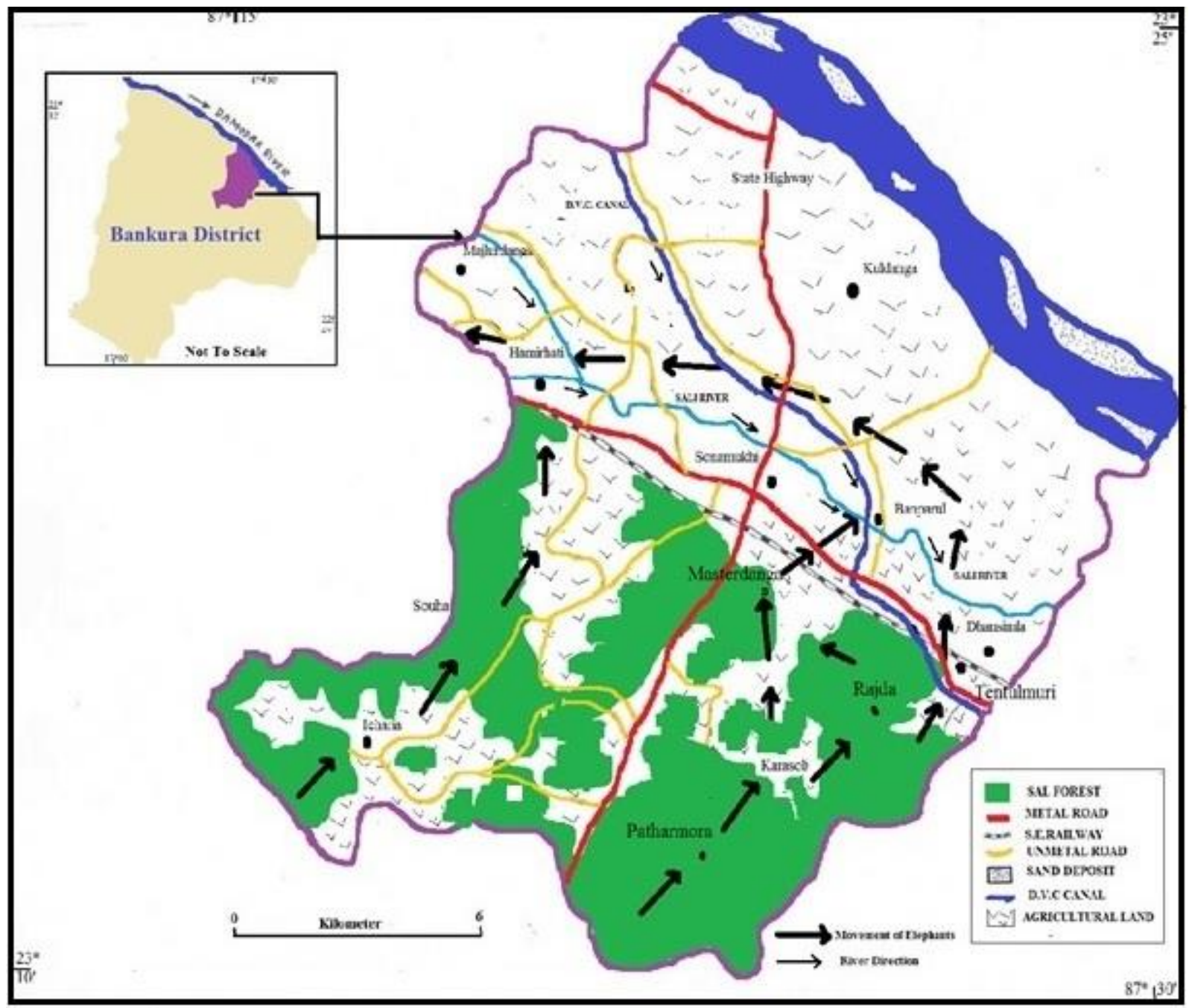

Figure 6: Movement of Elephants in Sonamukhi block (2000-2016)

Source: Travel track recorded by the authors with GPS and perception study of the villagers, 2016

\section{HEC in Sonamukhi Block}

Rural people set up their dwelling place in a natural forest environment where the inhabitants always interact with the physical environment in one hand and sometimes interact or indulge into conflicts with wild animals like the elephant, wild hogs, foxes, snakes and different kinds of birds, etc. Each G.P. consists of 10 to 12 mouzas. Every mouzas or villages are located within and/ or adjacent to the forest. All the villages are connected with small red unmetalled roads. Sal (Shorea Robusta) is the dominant species. Natural sal tree covers the southern part of Sonamukhi block. The other predominant species are Palash (Butea Monosperma), Mahua (Madhuca Indica), Kendu (Diospyros Melanoxylon) and Piyal (Buchanania Cochinchinensis) etc.The second dominant species are eucalyptus
(Eucalyptus Globulus) and akashmoni (Acacia Auriculiformis) trees, which are found in the vacant forest area or side of the unmetal roads. Near about $50 \%$ of the total block is covered by Sal, Palash, Mahua, Kendu, Eucalyptus and Akashmoni trees. The rural settlement and agricultural land occupy some of the areas in the forest.

The agricultural lands are situated beside or in front of the small settlement units. The villagers cut the forest trees for their domestic needs and expand their agricultural land. Not only that the farmers made their paddy cultivating farms near the agricultural lands by cutting the trees. People collect woods from the forest and use as fuel for their daily life. Due to unawareness, local people are not only collecting the forest twigs but also cutting the sal trees indiscriminately. 
Spaces, as well as food-water crises, are the fundamental causes of the HEC in Sonamukhi block. Land use change is one of the important indicators of environmental change that affects ecological balance, which directly or indirectly influences the habitat or the dwelling place of the elephants. Destruction of the forest through encroachments, shifting cultivation, monoculture, and artificial plantations with exotic species are the major threatening to the survival of the elephants (Choudhury, 2004). Encroachment in forest and development activities, like constructions, expansion of the agricultural land is destroying and fragmenting the wildlife habitats and migration routes of wild elephants. As human beings are considered as economic men, and they always choose short-term enormous economic gains rather than long-term environmental sustainability, thereby, human's needs are progressively transferred into greed.
Population pressure, expansion of agricultural land, shifting agriculture, forest fire, expansion of settlements and erroneous social forestry is not only encroaching the forest area but also changing the forest ecosystem. These are all leading to space, food, and water crisis to the inhabitants of the forest ecosystem in general and the wild elephants in particular (Figure 7). So, the wild elephant herds are compelled to raiding crops from the agricultural lands and in the household storage. The villagers are using unscientific practices like the throwing of sharp stone, firecracker, and hullo (burning flares) (Santra et al., 2007; Santiapillai et al., 2010) etc., to save their agricultural products which they regularly nurtured and input their total physical efforts and money. Sometimes the hulloes are stuck at the back of the elephants, and the herds then turn out to be more violent. As a result, the herd become more ferocious and injured men or sometimes even killed (Table 3, Figures 8 and $9 a, b, c, d$, and e).

\begin{tabular}{|c|ccc|c|c|c|}
\hline \multicolumn{7}{|c|}{ Table 2 Death of Human/ Livestock and Destruction of Wealth by the Elephant Herds, } \\
2015-16 & $\begin{array}{c}\text { Crop raiding } \\
\text { from } \\
\text { agricultural } \\
\text { land (\%) }\end{array}$ & $\begin{array}{c}\text { Crop raiding } \\
\text { from the } \\
\text { houses (\%) }\end{array}$ & $\begin{array}{c}\text { Houses } \\
(\%)\end{array}$ & $\begin{array}{c}\text { Vegetables } \\
(\%)\end{array}$ & $\begin{array}{c}\text { Human } \\
\text { Death } \\
\text { and } \\
\text { Injury } \\
(\%)\end{array}$ & $\begin{array}{c}\text { Livestock } \\
\text { Death } \\
\text { and } \\
\text { Injury } \\
(\%)\end{array}$ \\
\hline Dhansimla & 12.81 & 3.54 & 1.36 & 5.72 & 1.36 & 0.27 \\
\hline Manikbazar & 11.99 & 4.09 & 1.36 & 5.18 & 0.82 & 0.82 \\
\hline Panchal & 7.63 & 3 & 1.09 & 4.09 & 0.54 & 0.82 \\
\hline Kochdihi & 9.54 & 1.63 & 1.1 & 3.82 & 1.09 & 0.54 \\
\hline Hamirhati & 7.36 & 1.36 & 1.36 & 3.54 & 1.09 & 1.09 \\
\hline Total & $\mathbf{4 9 . 3 3}$ & $\mathbf{1 3 . 6 2}$ & $\mathbf{6 . 2 7}$ & $\mathbf{2 3 . 3 4}$ & $\mathbf{4 . 9}$ & $\mathbf{3 . 5 4}$ \\
\hline
\end{tabular}




\begin{tabular}{|c|c|c|c|c|c|}
\hline Years & Place & $\begin{array}{l}\text { Human } \\
\text { Death }\end{array}$ & $\begin{array}{l}\text { Human } \\
\text { Injury }\end{array}$ & $\begin{array}{l}\text { Crop Damage } \\
(\mathrm{Ha})\end{array}$ & $\begin{array}{c}\text { Hut } \\
\text { Damage }\end{array}$ \\
\hline \multirow[b]{2}{*}{$2013-14$} & Bankura (North) & 9 & 17 & 1122 & 449 \\
\hline & $\begin{array}{c}\text { Sonamukhi } \\
\text { Range }\end{array}$ & 1 & 1 & 241.98 & 31 \\
\hline \multirow[b]{2}{*}{$2014-15$} & Bankura (North) & 13 & 22 & 1382 & 1131 \\
\hline & $\begin{array}{c}\text { Sonamukhi } \\
\text { Range }\end{array}$ & 3 & 7 & 459 & 162 \\
\hline \multicolumn{6}{|c|}{ Source: D.F.O, Bankura North Division, Bankura } \\
\hline
\end{tabular}

Encroachment of Forest Area Because of

Population Pressure

Expansion of Agricultural

Fields

Shifting Agriculture

Forest Fire

Increasing Settlement

\section{Error Social Forestry \\ Because of \\ Eucalyptus and Akashmoni \\ Plantation in Large Scale}

Shortage of Food and Water Because of

Absence of Big Pond, Tank and

Reservoir, Steep Forest Slope

Encroachment of Forest Area by

Human Settlement, Agricultural

Field and Eucalyptus, Akashmoni

Plantation

Figure 7: Causes of HEC in Sonamukhi block Source: Perception study of the respondents, 2016 


\begin{tabular}{|c|c|c|c|c|c|}
\hline \multicolumn{2}{|c|}{$1990-2000$} & \multicolumn{2}{|r|}{$2000-2010$} & \multicolumn{2}{|r|}{$2010-2015$} \\
\hline \multirow{5}{*}{\multicolumn{2}{|c|}{$\begin{array}{l}\text { Crop Damage } \\
\text { (particularly milky stage of paddy) } \\
\text {. Few House Damage } \\
\text {. Damage of newly planted sal trees }\end{array}$}} & \multicolumn{2}{|c|}{$\begin{array}{l}\text {. Attack Household Storage } \\
\text {. Raid Food, Paddy Storage } \\
\text {. Damage of Vegetables and Fruit } \\
\text { Crops (potato, sugarcane, banana etc.) }\end{array}$} & \multicolumn{2}{|c|}{$\begin{array}{l}\text { Occurrence of Human Death and Injuries } \\
\text { 1. Disturbances of Daily Human activities } \\
\text { 1. Damage of Crops and Kitchen garden } \\
\text { 1. Invasion of Paddy, Food Storage } \\
\text { 1. Breaking of Hut and Semi - pucca houses } \\
\text { | in the time of Searching Food } \\
\text { 1. Damage of Horticultural Crops } \\
\text { | (potato, cabbage, brinjal and caulfflower etc.) } \\
\text {. Damage of Fruit Crops } \\
\text { (banana, jackfruit and suigarcane) }\end{array}$} \\
\hline & & Causes & $\begin{array}{l}\text { Multiple composition of } \\
\text { agricultural crops } \\
\text { Available of food fodder } \\
\text { throughout the year } \\
\text { Fertile land providing food to } \\
\text { the elephants } \\
\text { Error plantation (eucalyptus, } \\
\text { akashmoni are not suitable } \\
\text { fodder for the elephants) } \\
\end{array}$ & Causes & $\begin{array}{l}\text { Changing cropping patterns } \\
\text { (cultivation of green chilli, turmeric } \\
\text { and ginger) } \\
\text { Travel track of the elephants } \\
\text { encroached by construction } \\
\text { Local people brusting cracker } \\
\text { and throwing stone }\end{array}$ \\
\hline & & $\begin{array}{c}\text { Attacked } \\
\text { by }\end{array}$ & $\begin{array}{l}\text { Migratory and Local } \\
\text { elephants (more than } 50 \text { no.) }\end{array}$ & \multirow{2}{*}{$\begin{array}{c}\text { Attacked } \\
\text { by }\end{array}$} & \multirow{2}{*}{$\begin{array}{l}\text { Migratory and Local elephants } \\
(90-100 \text { no.) }\end{array}$} \\
\hline & & \multirow[t]{2}{*}{ Duration } & \multirow{2}{*}{$\begin{array}{l}\text { Migratory: Sept.to Dec( } 4 \text { months } \\
\text { Local throughout the year }\end{array}$} & & \\
\hline & & & & \multirow{2}{*}{ Duration } & \multirow{2}{*}{$\begin{array}{l}\text { Migratory: Sept. to Dec. (4 months) } \\
\text { Local throughout the year }\end{array}$} \\
\hline Causes & $\begin{array}{l}\text { Absence of food and } \\
\text { water in the forest }\end{array}$ & & & & \\
\hline Attacked by & $\begin{array}{l}\text { Migratory elephants } \\
(20-30 \text { no. })\end{array}$ & & & & \\
\hline Duration & & & & & \\
\hline
\end{tabular}

Figure 8: Destruction patterns by the Elephants and its temporal change Source: Prepared by the authors using the perception of the villagers, forest rangers, District Forest Officers, Bankura District, 2016 

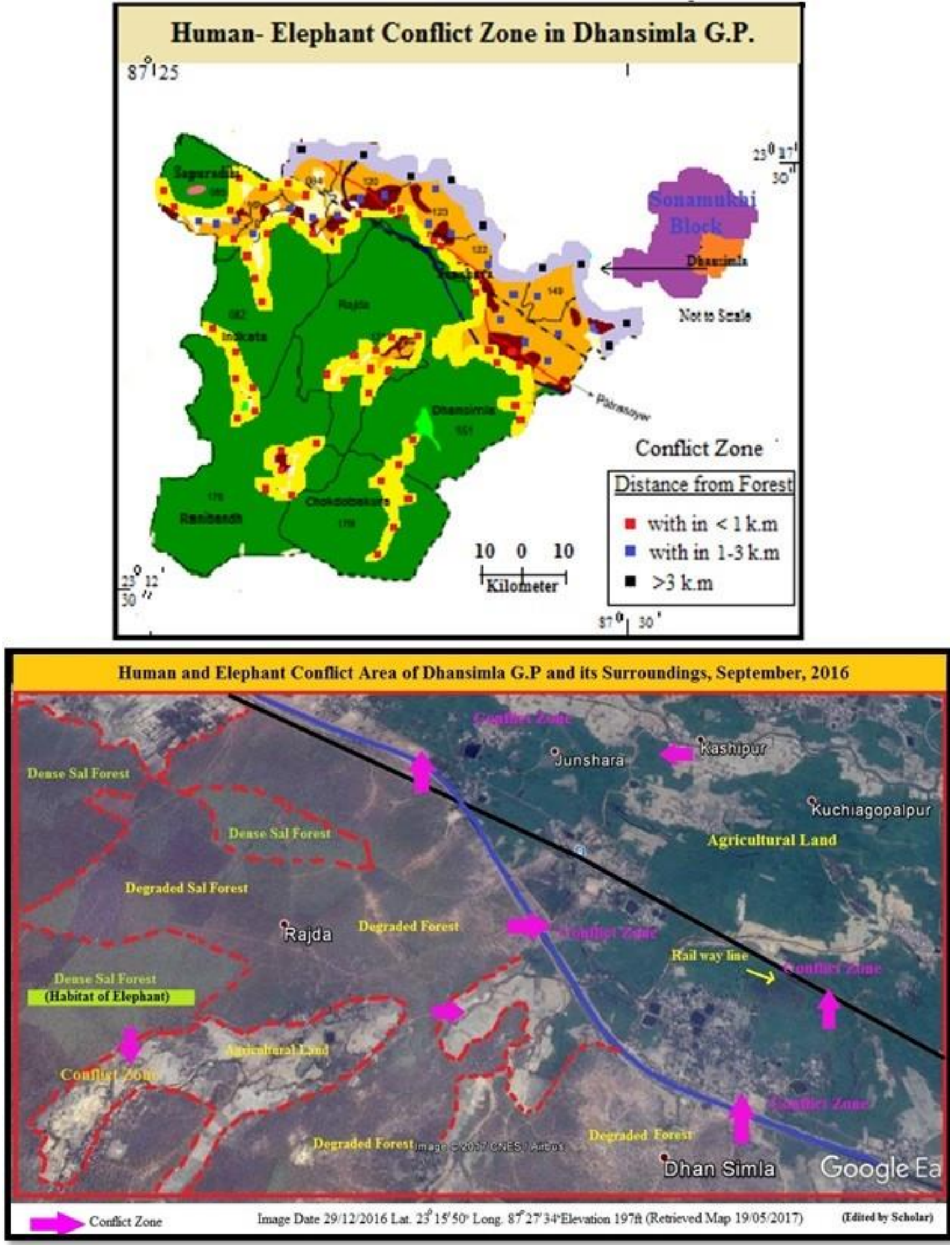

Figure 9a

Source: Prepared by the authors on Google Image (Image Date 29.12.2016, retrieved on 19.05.2017) 

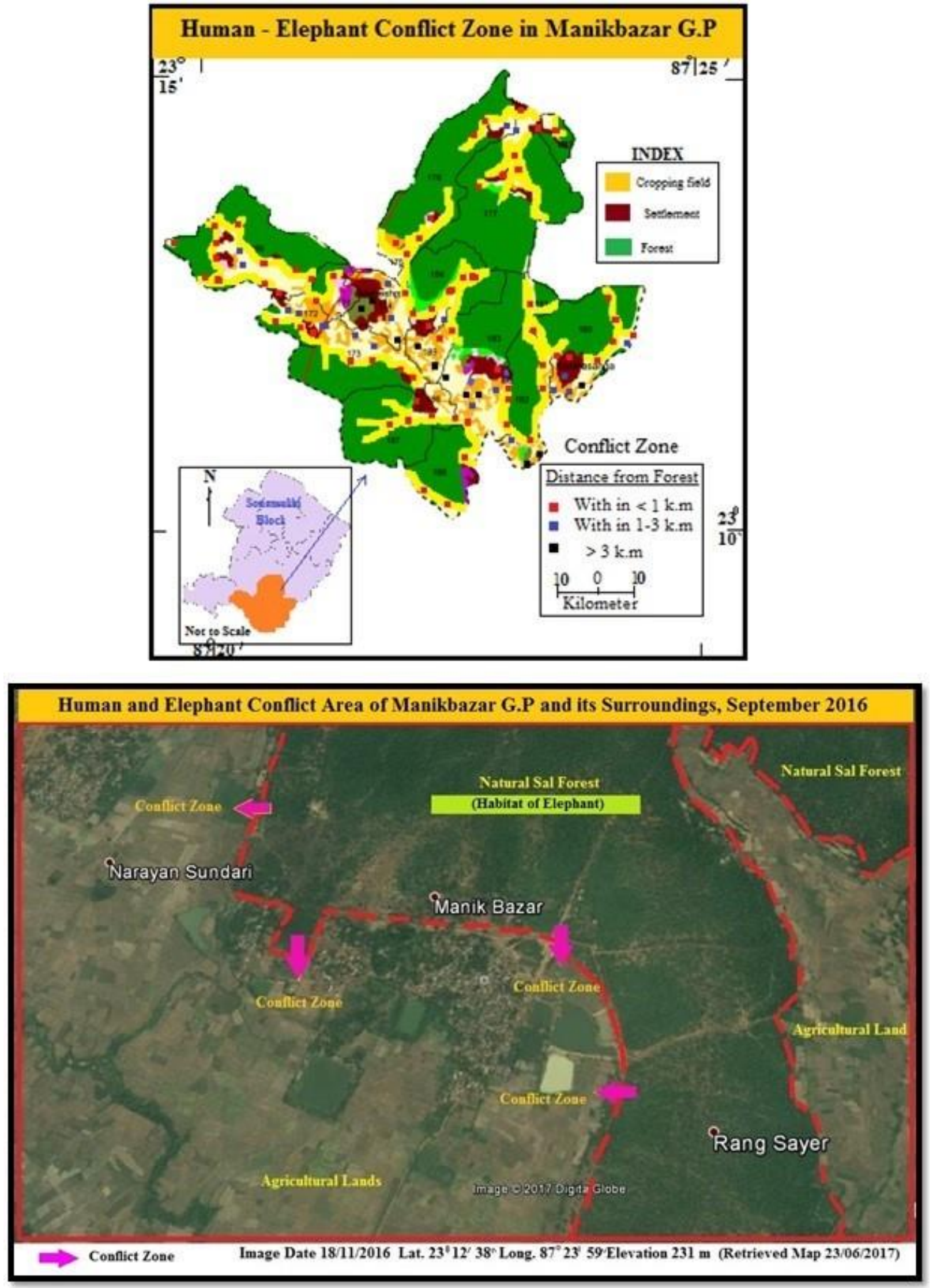

Figure 9b

Source: Prepared by the authors on Google image (Image Date 18.12.2016, retrieved on 23.06.2017) 


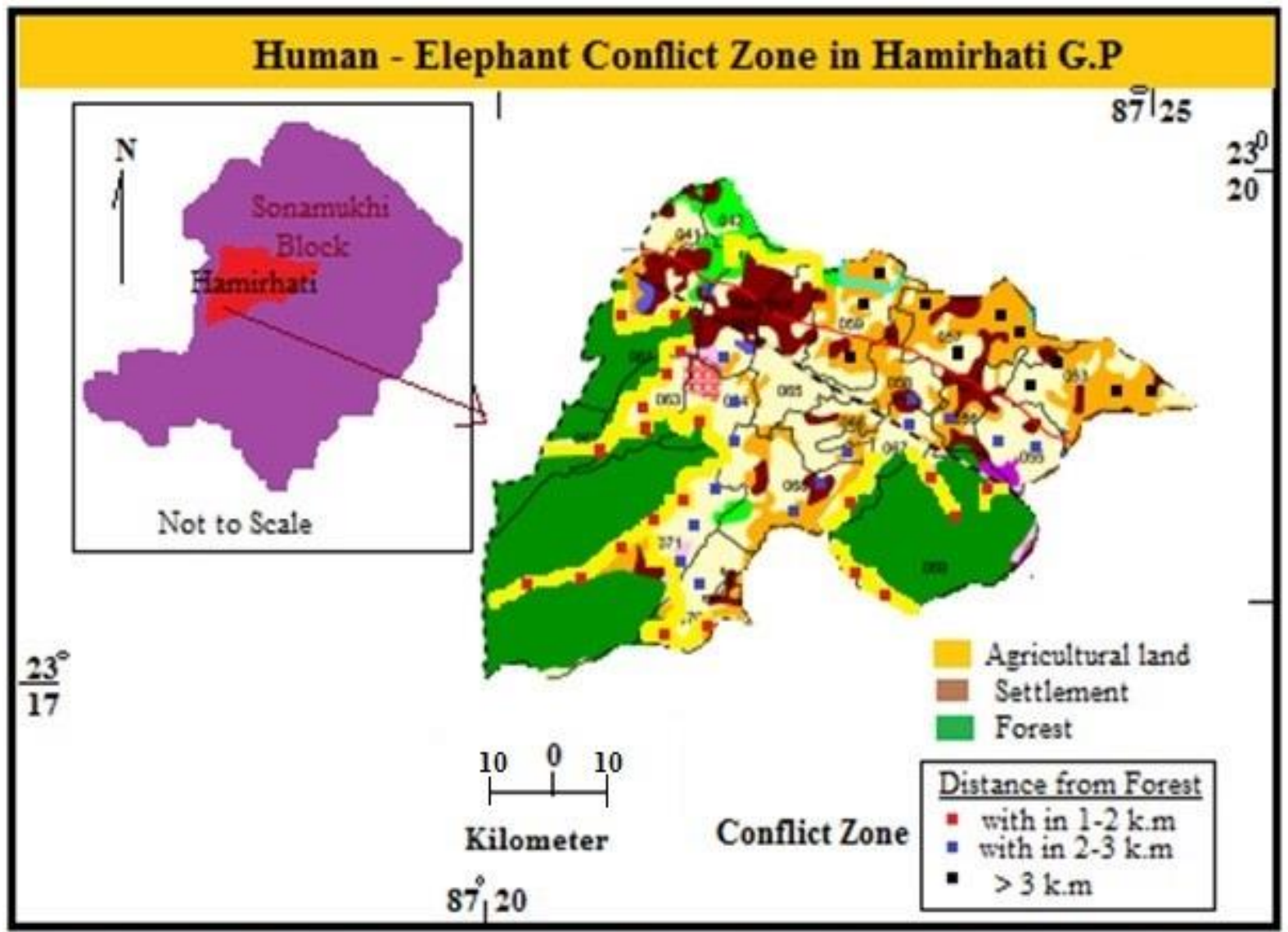

Human and Elephant Conflict Area of Hamirhati G.P and its Surroundings, September 2016

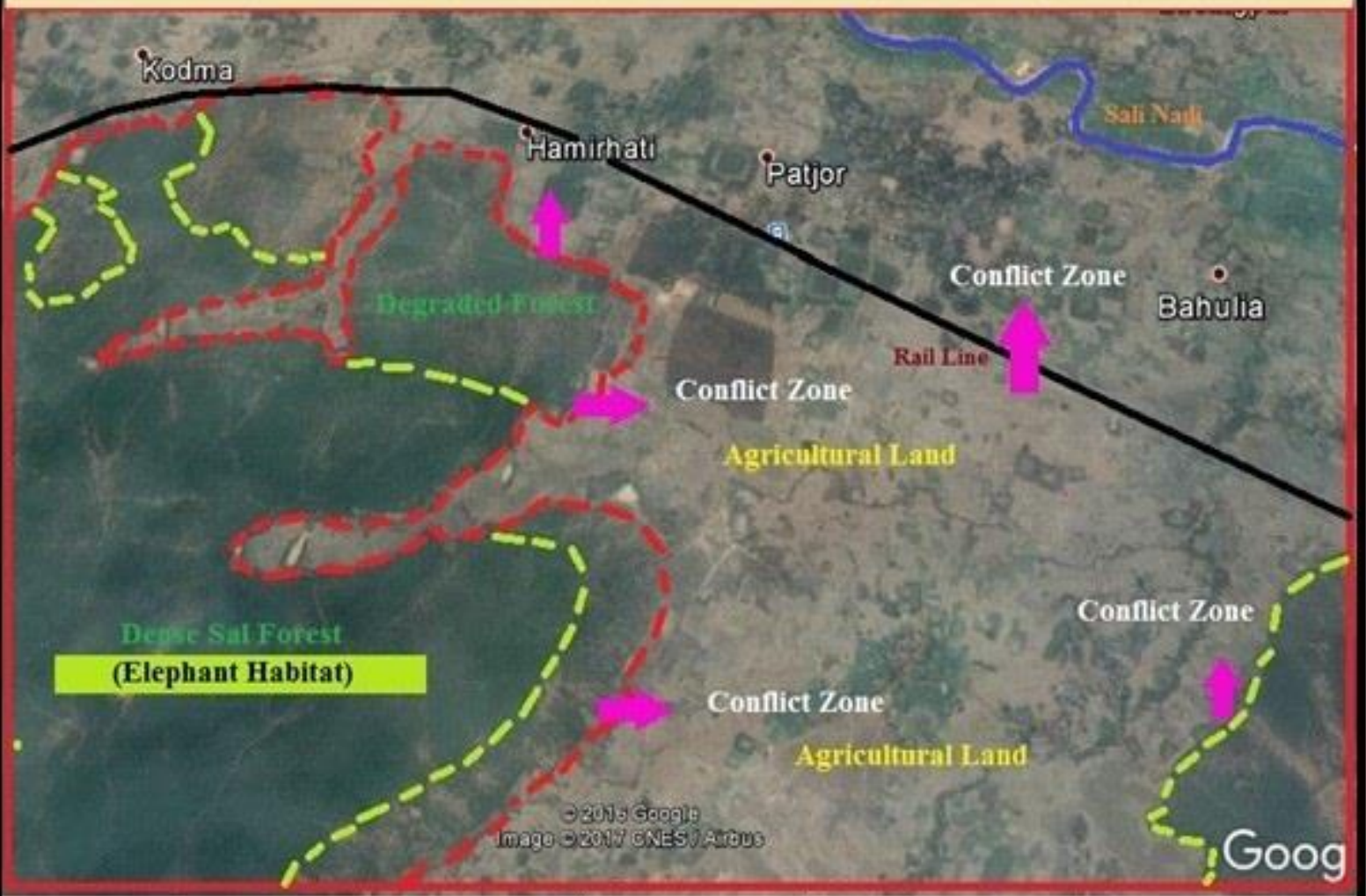

$\Rightarrow$ Confict ZoneImage Date 29/12/2016 Lat. $23^{6} 18^{\prime} 5^{\prime} 4^{\prime}$ Long. $87^{\circ} 21^{\prime} 1^{\prime}{ }^{\prime}$ Elevation 231 ft(Retrieved Map 2306201

Figure 9c

Source: Prepared by the authors on Google image (Image Date 29.12.2016, retrieved on

23.06.2017) 

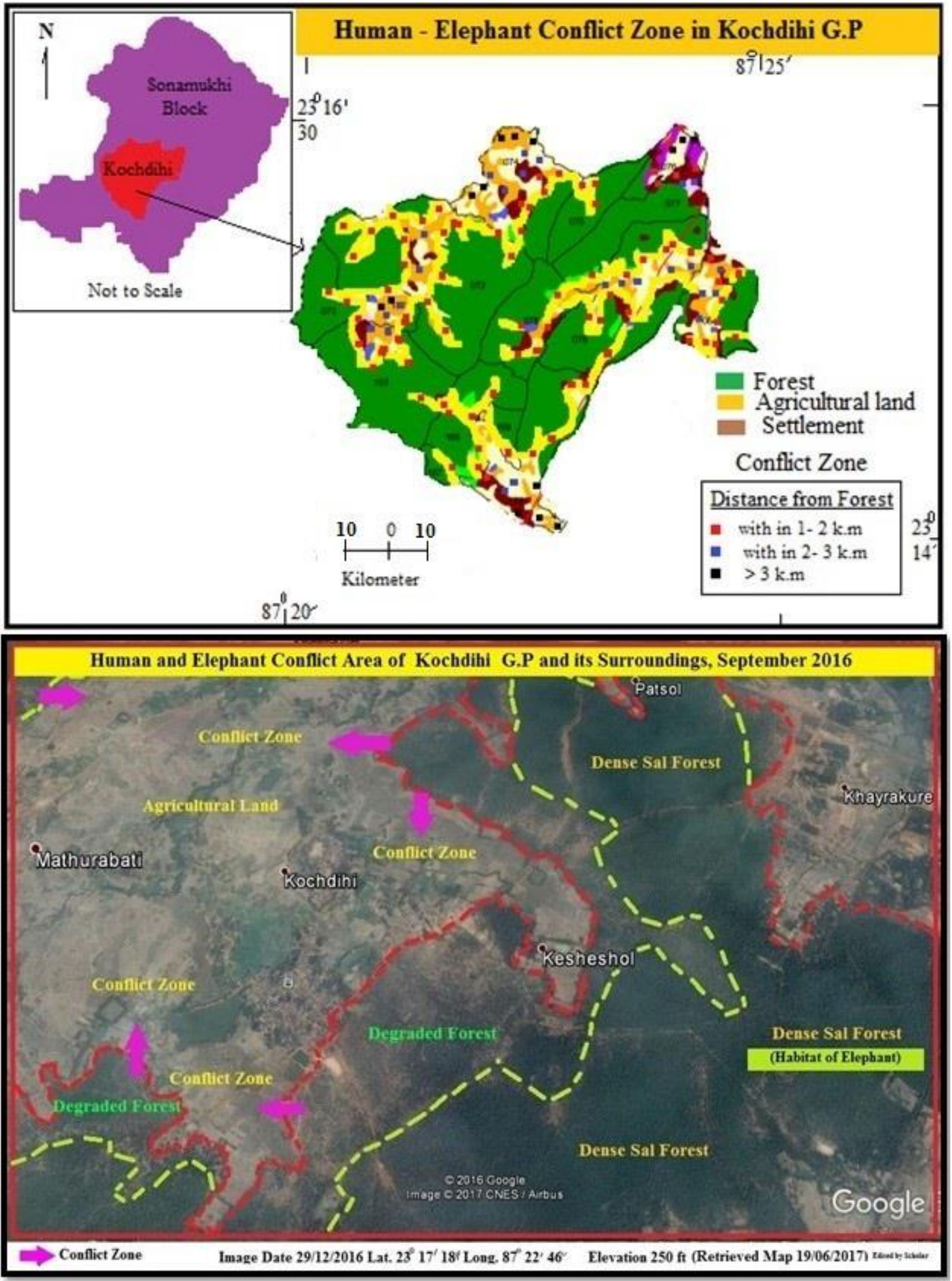

Figure 9d

Source: Prepared by the authors on Google image (Image Date 29.12.2016, retrieved on 23.06.2017) 


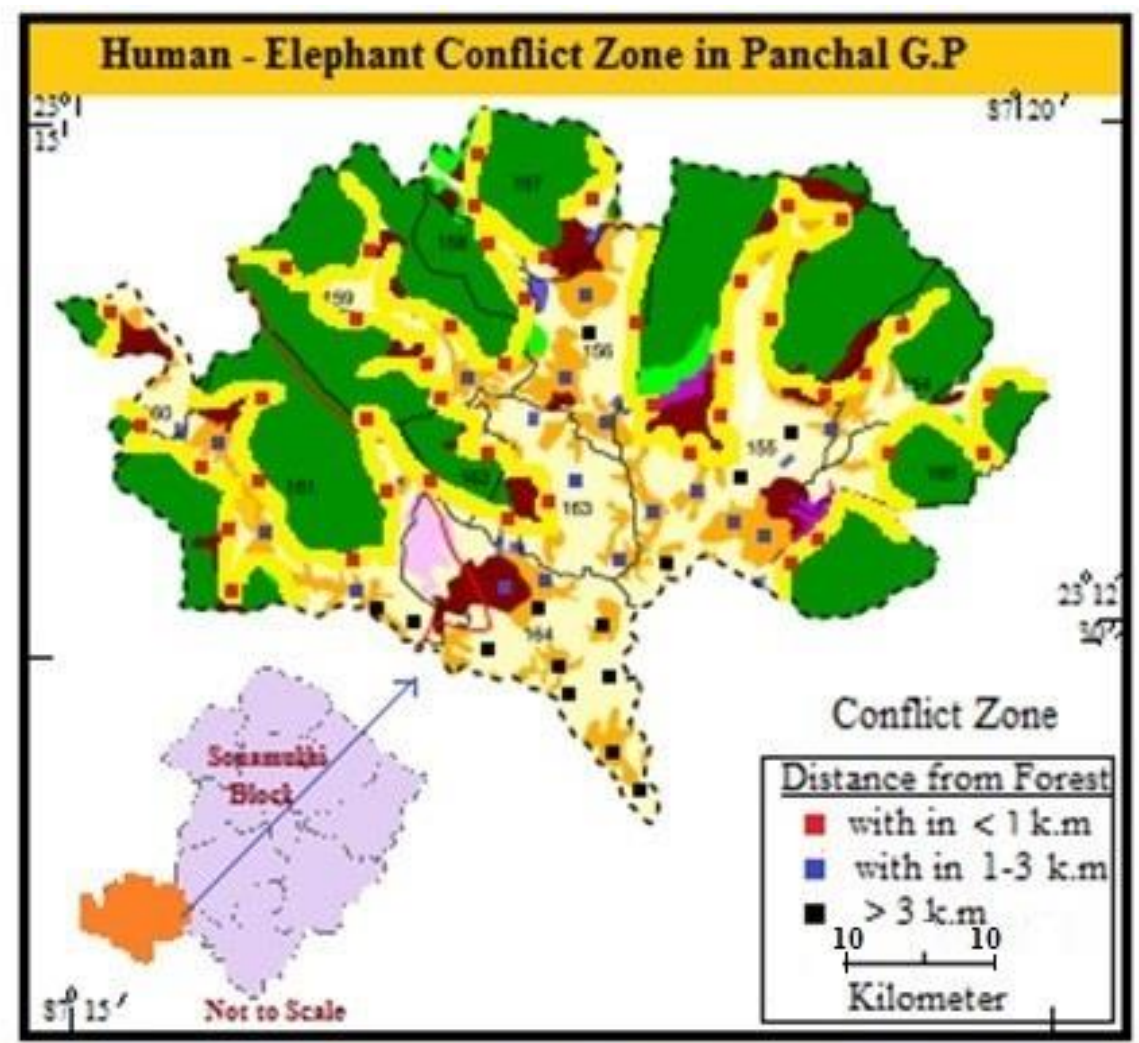

Human and Elephant Conflict Area of Panchal G.P and its Surroundings, September 2016

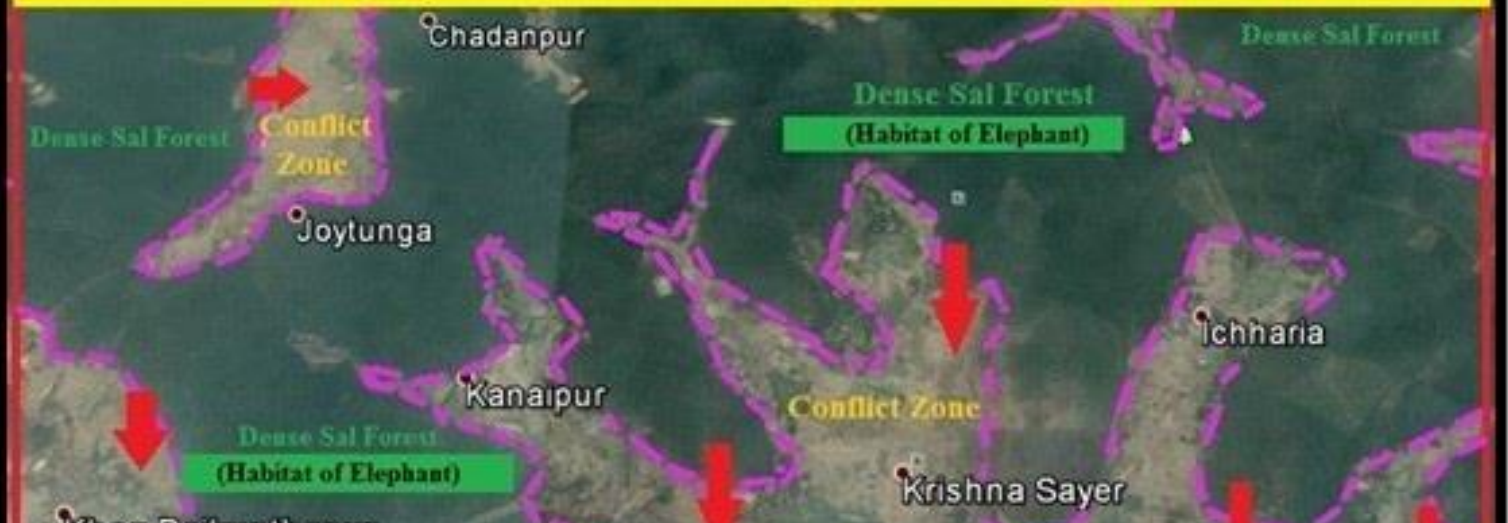

Khag Baikunthapur

Confict Zore

\section{Aralkola}

Agriculturat Land

Panchgizone soogh

Conflict Zone Image Date 29/12/2017 Lat. 23' 14' 30' Long. 87 17' 30 Retrieved Date 23/06/2017 (Edited by the Scholar)

Figure $9 e$

Source: Prepared by the authors on Google image (Image Date 29.12.2016, retrieved on

19.06.2017) 


\section{Conflicts Created by Both the Migratory and the Local Elephants in Sonamukhi Block}

Most of the conflict occurs in the cropping fields from the month of August to January. The utmost frequencies of the elephant's invasions take place in the cropping fields within 0.5 to $1.5 \mathrm{~km}$ far from the forest, and the conflict incidences gradually decrease far away from the forest. The trend line of the scatter diagram is purely negative, and also the correlation $(r)$ value is - 0.9577 (Figure 10). Therefore, there is a strong negative relationship between the distance $(X)$ from the forest and the conflict frequency $(Y)$ of migratory elephants in Sonamukhi block. Here, the calculated ' $\mathrm{t}$ ' value (17.37) is greater than the tabulated ' $t$ ' value (3.37). So, the relation is significant at $99 \%$ significant level. In the time span from August to January, the migratory elephants cause the conflicts rather than the local elephants. These migratory elephants destroy the agricultural lands usually in the evening or night during the milky stage and the harvesting time of Aman paddy. The milky stage of paddy is very much attractive to the elephant herds (Kulandaivel, 2010) (Figure11).
However, the local elephants permanently live in the natural habitats of sal forest in Sonamukhi block. Sometimes, these herds come like a king and enter into the cropping fields, eat the crops according to their needs. It is interesting to note that the herds do not like to eat the same crops every day. Instead, they eat horticultural crops as vegetables like potatoes, brinjals, tomatoes, cabbages, cauliflowers, pumpkins, and gourds, and other crops like paddy, wheat, and oilseed and also fruit crops like banana, sugarcane, jackfruit, and cucumber etc. (Nature India, 2016). The herds wander from one village to another village and from one cropping field to another field in search of these types of crops. So, the destruction frequencies are not confined to a limited area. The herds walk along a distance in search of their favourite foods. The correlation $(r)$ between the distance $(X)$ from the forest and the conflict frequency by the local elephants $(\mathrm{Y})$ is -0.9726 and the relation are strongly negative. Here, the calculated ' $\mathrm{t}$ ' value (9.35) is greater than the tabulated ' $\mathrm{t}$ ' value (3.37), and the relations are significant at $99 \%$ significant level (Figure 12). The depredation of the local elephants occurs throughout the year either during the daytime or in the night.

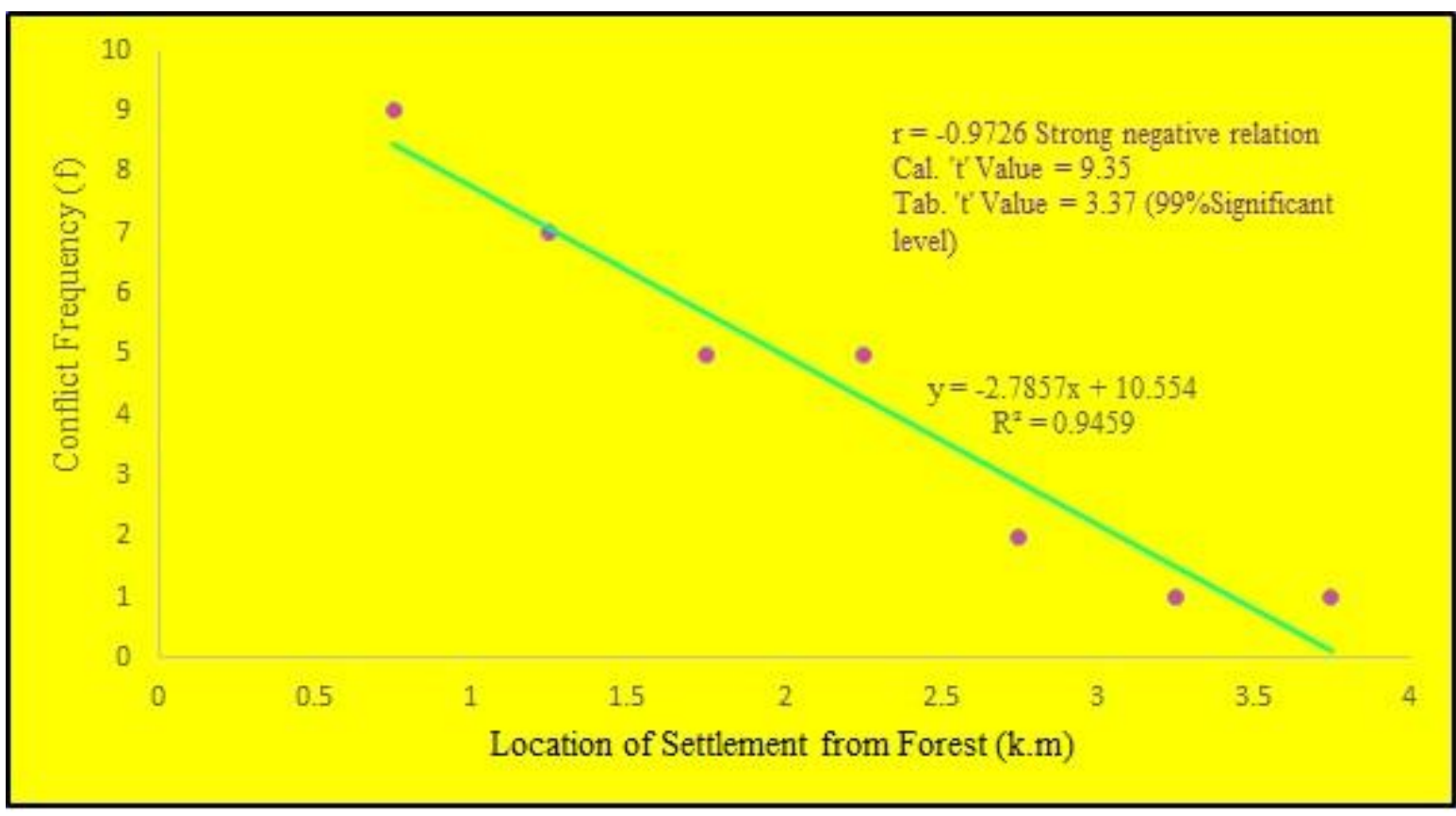

Figure 10: Relationship between distance and the conflict by the local Elephants in Sonamukhi block (January 2016 - March 2017) Source: Data collected by the authors during field survey 


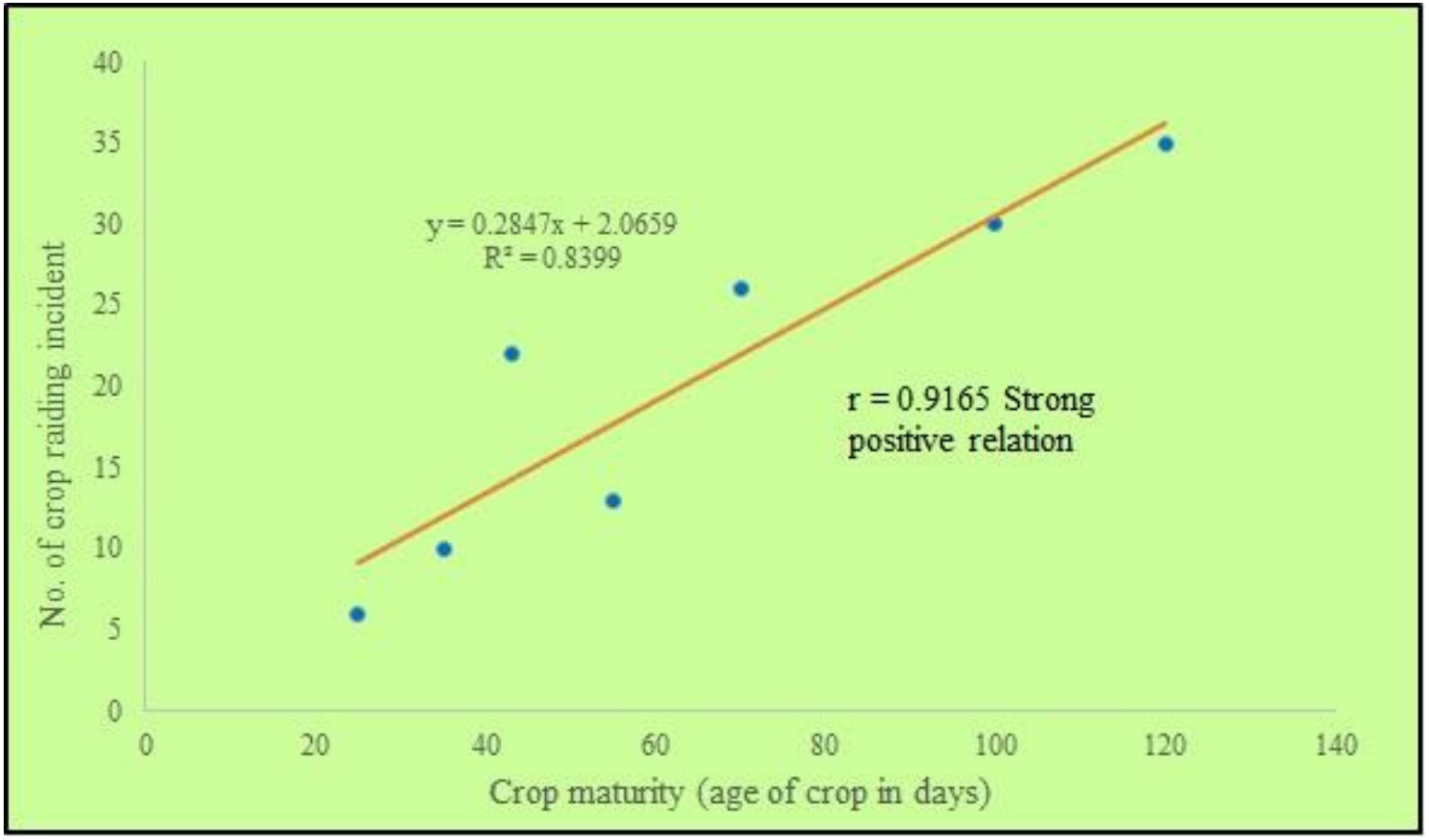

Figure 11: Graph showing the relationship between Crop Maturity and the Number of Raiding Incidents (2015- 2017)

Source: Data collected by the authors during field survey, 2016

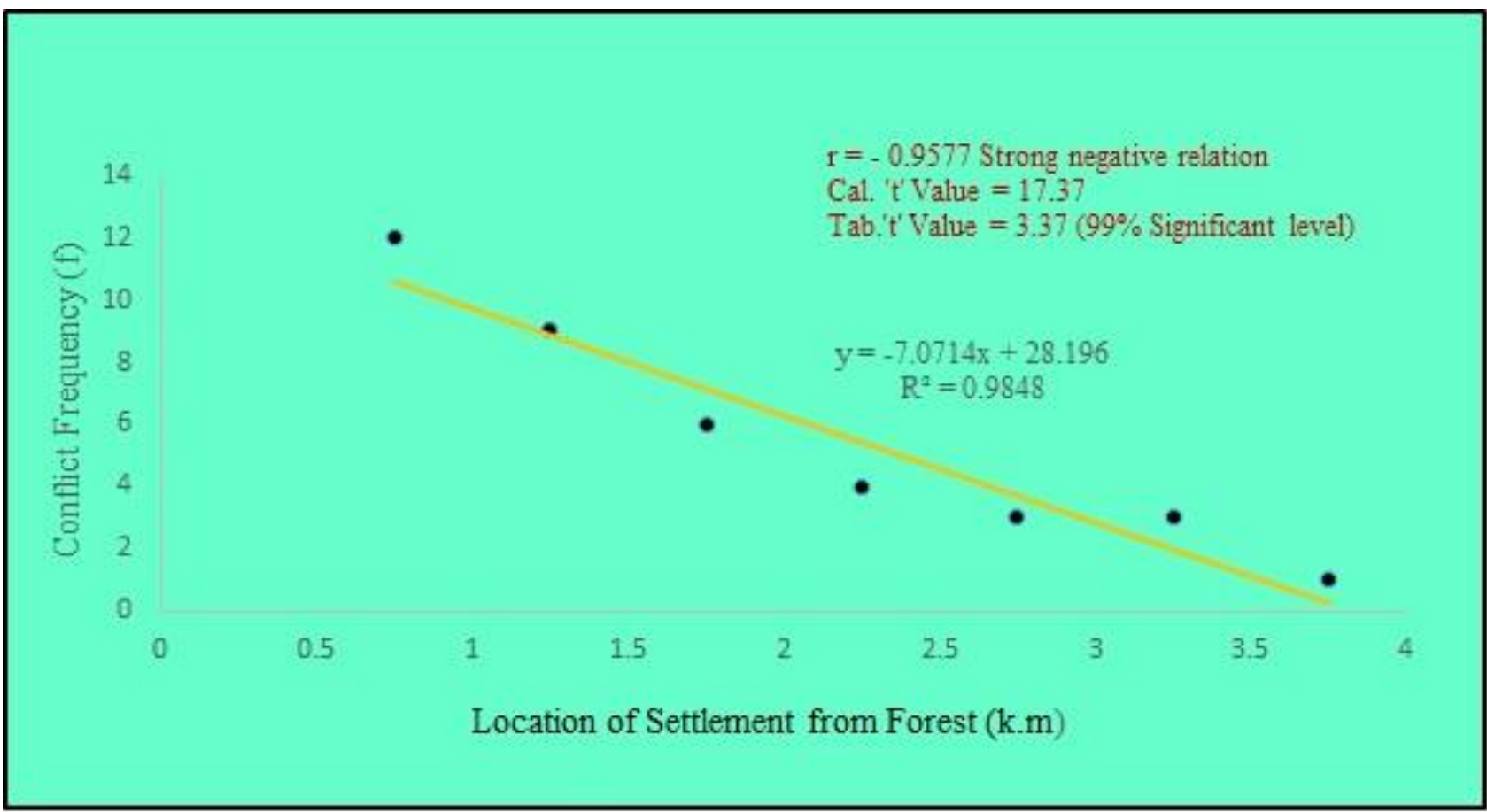

Figure 12: Relationship between distance and the conflict by the migratory Elephants in Sonamukhi block (January 2016- March 2017)

Source: Data collected by the authors during field survey, 2016

\section{Seasonal Conflicts between Humans and} Elephants in the Study Area

Earlier, before the year 2000, the elephant herds used to enter into the paddy fields and rarely raided crops from the households' storage, but in recent times, the same incidents have been occurring throughout the year. The higher frequency of HEC incidents during the rainy season probably stems from the 
maturation of crops (paddy, corn, beans, sugarcane) (Chen et al., 2016).

When the foods are available in the forest, the herds do not invade anywhere although the paddy fields are full of their favourite foods when the herds have faced much food crises in the forest, then the herds raid the paddy from the fields to fulfil their huge calorific demand. Sometimes, when the foods are not sufficient in the forest and agricultural fields, then the herds enter into the villages and raid foods from the households' storage. During the times of searching and raiding foods, the herds sometimes break the walls of the houses, mud houses, paddy, farm storage, etc. (Table 2). In the autumn and the winter seasons, damage, caused by the herds, are greater than the other seasons. Because in these two seasons, there are more amounts of agricultural products available in the farmers' fields. In these seasons, both the local and migratory elephants invade the fields (Table 1 ).

In the winter seasons, the horticultural crop practices take centre stage. There are different types of vegetables like potatoes; the farmers cultivate brinjals, cabbages, cauliflowers, etc.
As the vegetables are short-term profitable products so, when the herds eat the vegetables and destroy the fields, the farmers face trouble because they cannot replant the vegetables as the seeds become unavailable and the climatic conditions unsuitable for those particular vegetables. The farmers face multiple losses like damage of production, loss of time, seeds, amount investments, and even their hard work. In the rest of the seasons, the fields are affected by the local elephants; those that come from the adjoining Ajodhya hills, and from Jhargram area of Paschim Midnapur. In the intervening cropping periods, the herds attack commercial cash crops like jackfruits, sugarcane, and bananas, etc. (Figures 13 and 14).

According to the farmers, the agricultural loss is greater not for eating but for roaming of the elephants in the fields when the farmers apply unscientific practices for driving out the herds. During the day, evening or night when the herds come from the nearby forests and enter into the cropping fields, the farmers are often confused to see the massive gathering of the elephant herds (Figures 15 and 16).

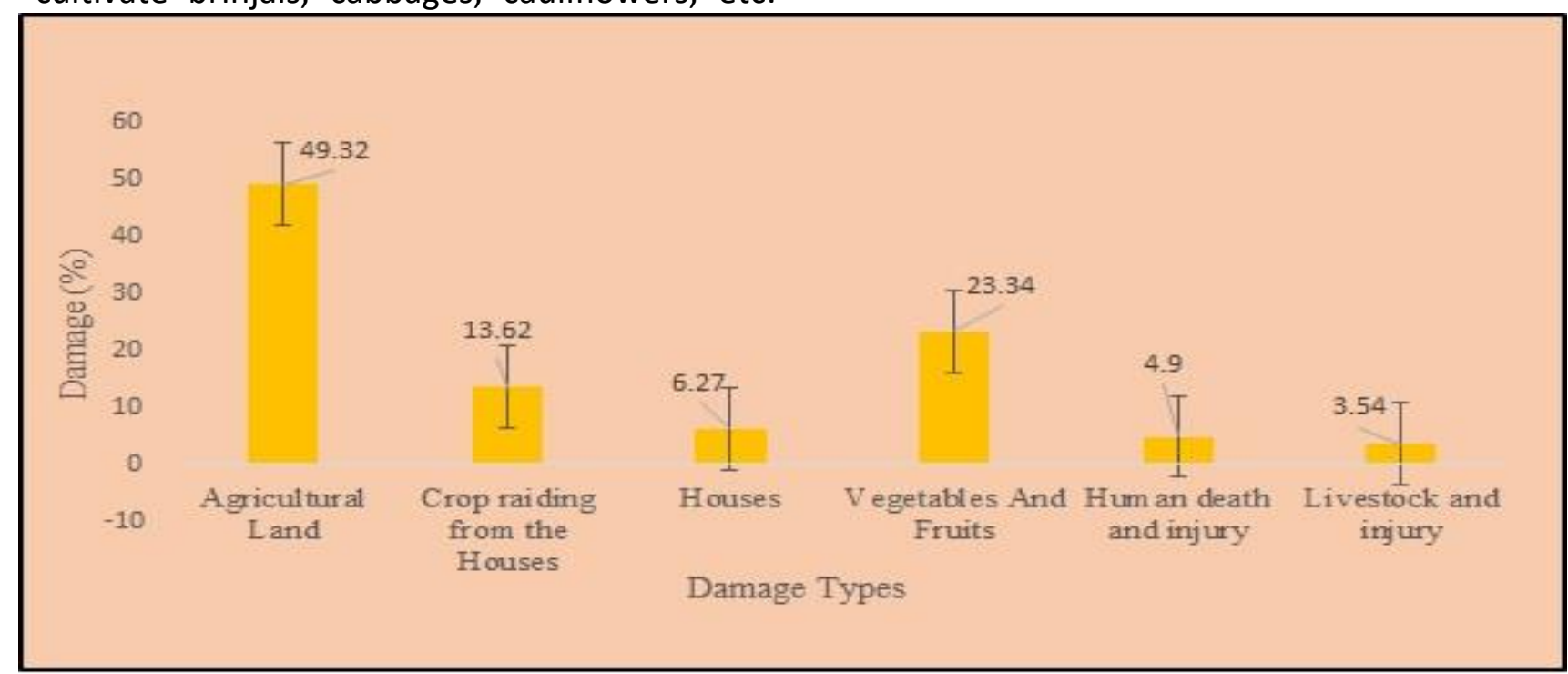

Figure 13: Destruction patterns by the wild Elephants in Sonamukhi block, 2016 Source: Data collected by the authors during field survey, 2016 


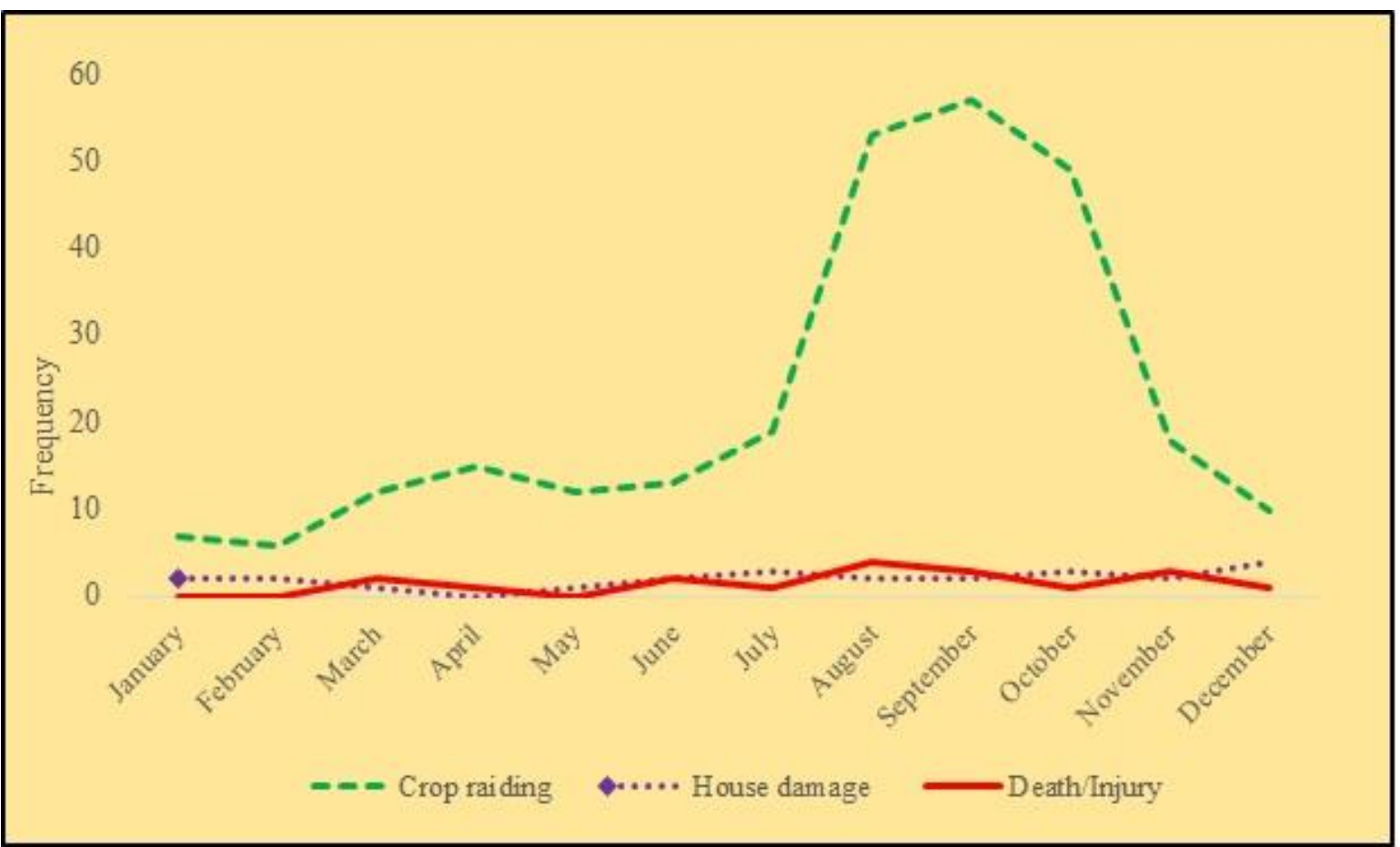

Figure 14: Monthly frequency of crop raiding/house damage/human death and injury in Sonamukhi block (2015-2016)

Source: Data collected by the authors during field survey, 2016

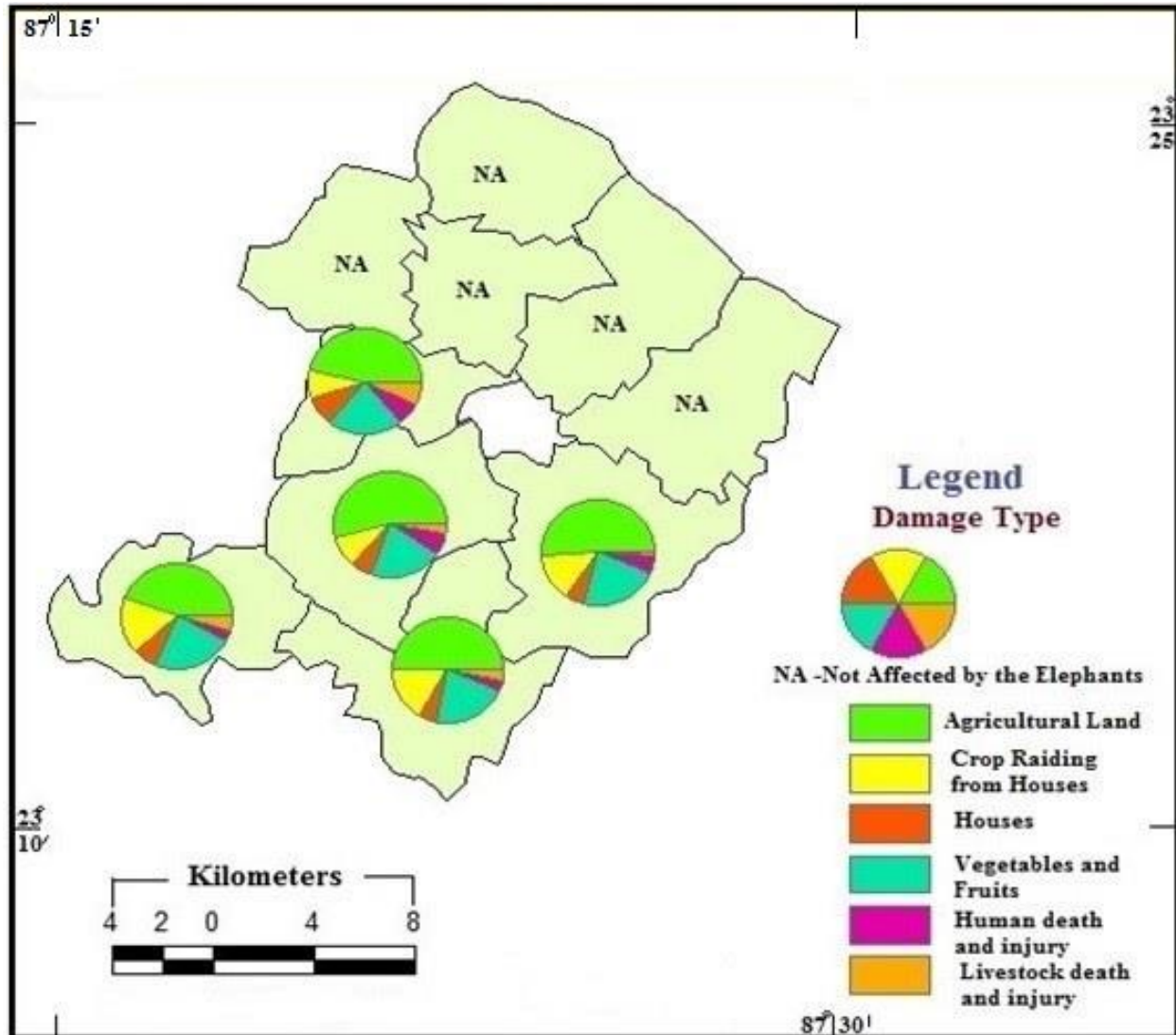

Figure 15: Types of destruction caused by Elephants in Sonamukhi block, 2016 Source: Prepared by the authors based on field survey, 2016 


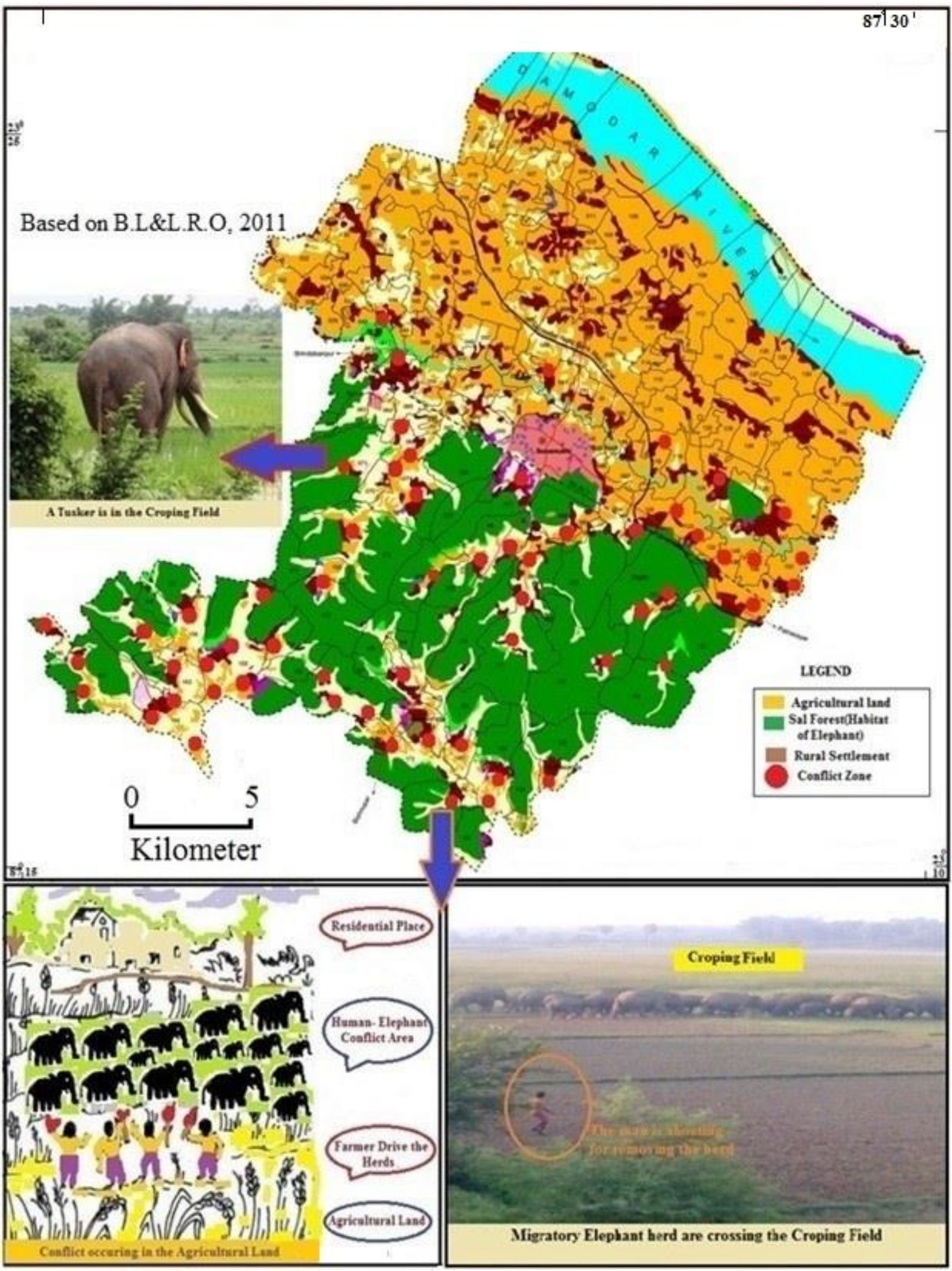

Figure 16: Overview of HEC in the study area (2016-March 2017)

Source: Land and Land Reform Department, Government of West Bengal, 2011 and conflict zone recorded by the authors with GPS during field survey, and the photograph retrieved, picture sketched by the authors, 2016 


\section{Conclusion}

The purpose of the current study was to display HEC in Sonamukhi Block, of Bankura District, West Bengal. From the analysis, it may be concluded that both need and greed of human society are present in the study area. The level of demand and aspirations, the standard of lifestyle and standard of the social status of the inhabitants are on the increase. The humans always aim to fulfil their demand and desire. They can do everything to reach their goals and fail to recall that they are also the species of earth ecosystem like the other species. As a member of the earth's ecosystem, the human beings are unable to remember that they have some responsibilities to cooperate, compromise and make adjustments with another species, and they do not waste a single moment about these thinking. In the study area, the migration of elephant herds is a common phenomenon because of their genetic character. The herds of local elephants have been living in the study area for ages. Therefore, it is their home, their territory. Humans have to realise that they have to live with the elephants. Of course, humans have to find ways to reduce HEC. For this, humans must avoid encroaching the dwelling place and the travelling tracks of the elephants. Other sustainable measures, which can minimise the HEC, are mentioned below:

- The plantation of exotic species like eucalyptus and akashmoni must be stopped in the vacant forest patches of the study area, and environmentally sustainable natural vegetations like (Sal, Palash, Mahua, Seris, etc.) are required to be planted in large- scale.

- Digging up many big ponds or tanks in the forest areas can perhaps help the herds to access water throughout the year. These activities have been recently started, but more is required. Organic fencing has been developed at strategic locations so that the conflicts may be reduced in the forest-based villages of the block.
- Crop compensation, advance information and the expenditure of medical treatment by the government must be increased in the affected block.

\section{References}

Anon, (2010). A Paradigm Shift in the Elephant depredation in South Bengal. Division Report of Bankura (North) Division.

Anonymous (2016). 'Nature India' Published by Nature India Group in Collaboration with B.C Software Service (pvt.) Ltd.

Anonymous (2015). DFO Bankura North Division, Government of West Bengal

Anonymous District Disaster Management Plan (2016). Census of India, 1971 to 2011, District Statistical Hand Book (2013-14), Bankura District, Bureau of Applied Economics \& Statistics, Go vernment of West Bengal

Anonymous (2013). The Hindu Newspaper (13th October 2013).

Baskaran, N. (2015). Behavioural Ecology of Asian Elephant (Elephas Maximus) and its implications for Landscape level conservation approach, International Symposium, Association of Indian Zoo and Wildlife Veterinarian, New Delhi.

Chanda, S. (1996). Man- Elephant Conflict in South West Bengal. (Joint Director of Sundarban Biosphere Reserve, West Bengal) IFS (1996 batch), pp. 1-8

Chartier, L., Zimmermann, A., and Ladle, R. (2011). Habitat loss and human-elephant conflict in Assam, India: does a critical threshold exist? Fauna \& Flora International, Oryx, 45(4), 528-533.

Chen, Y., Marino, J. Chen, Y., Tao, Q., Sullivan, C.D., Shi, K., and Macdonald, D.W. (2016). Predicting Hotspots of Human- Elephant Conflict to inform Mitigation Strategic in Xishuangbanna, South west China. PLos ONE 11 (9): eO162035. doi: 101371.

Choudhury, A. (2004). Human-elephant conflicts in Northeast India. Human Dimensions of Wildlife, 9(4): pp. 261-270. 
Gubbi, S. (2012). Patterns and correlates of human- elephant conflict around a South India reserve, Biological Conservation, Bengalooru, India, 148(1): pp.88-95.

Hoare, R. (1995). Opinions for the control of Elephants in Conflict with People. Pachyderm, 19, pp. 54-63

Inskip, C. \& Zimmermann, A. (2009). Humanfelid conflict: a review of patterns and priorities worldwide. Oryx, 43, pp.18-34.

Kulandaivel. S. (2010). A paradigm shift in the elephant depredation in South Bengal Bankura North Division, pp. 1-8.

Lee, P.C., and M.D. Graham. (2006). African elephants and human - elephant interactions: implications for conservation. International Zoo Yearbook 40: 9-19.

Madden, F. (2004). Creating coexistence between humans and wildlife: global perspectives on local efforts to address human-wildlife conflict. Human Dimensions of Wildlife, 9: 247-257.

Malley, O. (1908), Bankura District Gazetteer, pp. 5-25.

Palita, S. (2011). Challenges for wildlife conservation: Human- elephant conflict in Orissa, India, Proceedings on National Seminar on Wildlife Conservation and coexistenceEtd. pp.109-116.

Parker, G.E., Osborn, F.V., Hoare, R.E. and Niskanen, L.S. (eds.) (2007a). Humanelephant conflict mitigation: A training course for community-based approaches in Africa, pp. 86-100.

Parker, G.E., Osborn, F.V., Hoare, R.E. and Niskanen, L.S.A. (2007). Training Course for Community-Based Approaches in Africa Participant's manual, pp. 1-76.

Rohini, C.K., Aravdan, T., Vinayan, P.A., Ashok kumar, M., Das, K.S. (2016). An assessment of human-elephant conflict and associated ecological and demographic factors in Western Ghats of Kerala, southern India. Journal of Threatened Tax. 8(7): pp. 89708976.
Rohini, C.K., T. Aravindan \& K.S.A. Das (2015). Human-elephant conflict: Improved coexistence through multiple stakeholder interaction in Kerala, India. Gajah 42: pp. 32-35.

Santra, A.K., Samanta, A.K., Pan, S. (2007). Measures Adopted to Combat Migratory Elephants in South West Bengal Forests (Department of Livestock Production and Management, West Bengal University of Animal and Fishery Science, West Bengal, India)

Santiapillai, C. and Read, B. (2010). Would masking the smell of ripening paddy-fields help mitigate human- elephant conflict in Sri Lanka? Oryx, 44 (4): pp. 509-511

Santiapillai, C., Wijeyamohan, S., Bandara, G., Athurupana, R., Dissanayake, N., and Read, B. (2010). An assessment of the humanelephant conflict in Sri Lanka. Ceylon Journal of Science (Bio.Sci.), 39 (1): pp. 21-33.

Singh, A.K., Singh, R.R \& Chowdhury, S. (2002). Human-Elephant Conflict in Changed Landscapes of South West Bengal, India. The Indian Forester, 128: pp.1119-1132

Sukumar, R (1990). Ecology of the Asian elephants in Southern India. II Feeding habitats and crop raiding patterns. Journal of Tropical Ecology, 6: pp.33-53

Sukumar, R. (1992).The Asian Elephant: Ecology and Management. Second Edition Cambridge University Press, New York

Sukumar, R. (1994). Wildlife-human conflict in India: An ecological and social perspective. pp. 303-317. In: R. Guha (ed.) Social Ecology. Oxford University Press, New Delhi.

Walker, K. (2012). Labor costs and crop protection from wildlife predation: The case study of elephants in Gabon. Agricultural Economics, 43: pp. 61-73

Wilson, S., Davies, T., and Zimmermann, A. (2013). Understanding spatial and temporal pattern of human-elephant conflict in Asia, India. Cambridge Journal, Fauna and Flora International, Oryx, 1-1. 